\title{
ZNACZENIE WIERNOŚCI MAŁŻEŃSKIEJ W PERSPEKTYWIE WSPÓŁCZESNYCH ZAGADNIEŃ KOŚCIOŁA
}

Według nauczania Kościoła, małżeństwo, posiadające swoją podstawę w naturze mężczyzny oraz kobiety, będące stwórczym dziełem Boga, zostaje zawiązane w następstwie zgody stron pomiędzy osobami prawnie zdolnymi do tego, wyrażonej dobrowolnie oraz zgodnie z prawem. Zgoda małżeńska jest aktem woli, w którym mężczyzna i kobieta w nieodwołalnym przymierzu wzajemnie się sobie oddają i przyjmują w celu stworzenia małżeństwa ${ }^{1}$. Istotnym elementem tak rozumianej zgody małżeńskiej jest wzajemność w aprobacie powstającego w ten sposób związku. Przedmiotem zgody są osoby kontrahentów ${ }^{2}$. Tak więc poprzez małżeńskie przymierze mężczyzna i kobieta tworzą ze sobą wspólnotę całego życia ${ }^{3}$. Wspólnota ta służy wzajemnemu oddawaniu się i dopełnianiu stron ${ }^{4}$. Wynika z tego, że zjednoczenie małżonków posiada charakter przymierza, którego istotną cechą jest wierność. Najważniejszym zobowiązaniem wynikającym z przymierza małżeńskiego jest dochowanie wzajemnej wierności. Nierozerwalność małżeństwa sakramentalnego wynika stąd, że przez ten sakrament nowożeńcy zostali włączeni w trwałą jedność, jaka istnieje między Chrystusem i Kościołem, będącym Jego Mistycznym Ciałem. Jak Chrystus-Głowa i Kościół tworzą jeden, nierozerwalny organizm, tak i małżonkowie, uświęceni przez łaskę Chrystusa, stanowią aż do śmierci jedno, nierozerwalne ciało. „Co więc Bóg złączył - poucza Jezus Chrystus - niech człowiek nie rozdziela" (Mt 19,6). Małżeństwo sakramentalne jest zatem czymś więcej niż czysto ludzką umową i przyrzeczeniem wza-

KPK, kan. 1057, par. 1,2; KKK 1626-1628, 2201.

2 W. Góralski, Kościelne prawo matżeńskie, Płockie Wydawnictwo Diecezjalne, Płock 1987, s. 16; KKK 1639.

3 KPK 1055; KKK 1601, 1603; Obrzędy sakramentu matżeństwa dostosowane do zwyczajów diecezji polskich, Wyd. Księgarnia św. Jacka, Katowice 1996, 1.

4 M. Żurowski, Kanoniczne prawo matżeńskie Kościoła Katolickiego, Wyd. Księgarnia św. Jacka, Katowice 1987, s. 80. 
jemnej miłości, choć nawet ludzka tylko przysięga domaga się spełnienia tego, co się obiecało. Raz dane słowo zobowiązuje do wierności obietnicy.

Sama natura miłości wymaga trwałości małżeństwa. Niepoważnie brzmiałyby słowa przysięgi czasowej tylko miłości i wierności, np.: „Ślubuję ci miłość aż do momentu, gdy mi się znudzisz”, albo: „Będę cię bardzo kochać, dopóki będziesz piękna, zdrowa, miła dla mnie, dopóki mi będzie z tobą dobrze”, albo: „Ślubuję ci miłość aż do chwili, kiedy poznam kogoś milszego od ciebie". Bóg wymaga od człowieka miłości trwałej, biorącej odpowiedzialność za drugiego człowieka, miłości bezinteresownej, gotowej na wszystko, uznającej człowieka za wielką wartość, której nie można porzucić. Bezsensem byłyby małżeństwa czasowe, „na próbę", by się przekonać, czy drugi mi odpowiada pod względem erotycznym. Narzeczeni mają obowiązek poznać się wzajemnie jak najlepiej, czego domaga się dobro i trwałość ich przyszłego małżeństwa. Dla budowania wspólnego życia potrzebna jest pewna jedność w sprawach istotnych. Młodzi ludzie powinni zatem poznać charakter, wychowanie, światopogląd partnera życia, powinni korzystać z doświadczenia innych osób. Poznanie jednak nie może krzywdzić drugiego, co miałoby miejsce w przypadku przedślubnego współżycia lub w przypadku tworzenia „,próbnych” małżeństw. Trwałości i nierozerwalności małżeństwa wymaga także dobro dziecka. Potrzebuje ono rodziców i rodziny, w której panuje atmosfera jedności, opartej na miłości i wzajemnym poszanowaniu godności osobowej.

Ponieważ małżeństwo posiada swoje źródło w zamyśle stwórczym Boga, oznacza to, że jest ono wypełnianiem zbawczych planów Boga. Zatem przymierze małżeńskie posiada także charakter religijny. Potwierdzają to teksty biblijne, wedle których pojęcie przymierza jest jednym $\mathrm{z}$ centralnych $\mathrm{w}$ całej teologii zbawienia. Przyczyną tego jest to, że przymierze stało się instytucją ilustrującą zasadnicze stosunki między ludźmi i Bogiem. Chociaż źródłem treści w nim zawartych jest niewątpliwie sposób rozumienia go u ludów starożytnego Wschodu, to jednak Objawienie Boże nadaje im głębszy i pełniejszy sens.

Pojęcie „przymierza” (hebr. $m a$ - słowo to wywodzi się najprawdopodobniej ze źródłosłowu, który znaczy „więź, pęta”, co wskazuje na zobowiązujący układ, ideę „wiązania, łączenia”) jest jednym z naczelnych w Biblii i dlatego odgrywającym ważną rolę w historii zbawienia. Przymierze, to najogólniej, oficjalne porozumienie czy też umowa pomiędzy dwoma stronami, które przyjmują na siebie pewne wzajemne zobowiązania. Oznacza to, że obie strony posiadają także pewne przywileje. W świetle Biblii przymierze może być ugodą zawartą dobrowolnie pomiędzy ludźmi ${ }^{5}$, lub też pomiędzy narodami czy państwami ${ }^{6}$. Może ono też być narzucone stronie słabszej przez silniejszą ${ }^{7}$. Dlatego przymierze posiada

\footnotetext{
Rdz 31,44-54; 1 Sm 18,3.

Rdz 14,13; 1 Krl 5,26.

Joz 9; 1 Sm 11,1-2.
} 
charakter prawny i polityczny.Celem zawarcia przymierza jest ustanowienie i zapewnienie stanu pokoju, harmonijnej równowagi. Partnerzy zobowiązują się do postępowania zgodnego z postanowieniami przymierza, czyli do dołożenia wszelkich starań, żeby ustanowiona w przymierzu wspólnota trwała w przyjaźni i solidarności. Przymierze oznacza porządek pewnego międzyludzkiego związku w sensie wzajemnej przynależności i przyjaźni. Dlatego przymierze oznacza więź opartą na zobowiązaniu, obejmującą zarówno obietnice, jak i obowiązki oraz charakteryzującą się solidnością i trwałością .

W tekstach biblijnych przymierze staje się wzorem traktatu, jaki Bóg zawarł z Izraelem na górze Synaj. To przymierze wykazuje znaczne podobieństwa z traktatami, jakie zawierał na starożytnym Bliskim Wschodzie suweren ze swym wasalem. Dotyczy to zwłaszcza traktatów chetyckich z XIV i XIII wieku przed Chrystusem. Opowiadanie o przymierzu na Synaju ${ }^{9}$ zawiera także podstawowe elementy takiego traktatu, jakimi są: przedstawienie osoby proponującej traktat i dobra, które ona świadczyła ${ }^{10}$, wymagania ${ }^{11}$, oraz odczytanie traktatu i obrzędowy posiłek (por. $\mathrm{Wj} 24,7-11)^{12}$. Ta polityczna struktura przymierza podkreśla wagę relacji między Bogiem a Izraelem i tym samym wyklucza możliwość zawierania innych przymierzy ${ }^{13}$. Z kolei element prawny przymierza synajskiego wyraża się w wymaganiach, które są prawem obowiązującym naród. Wymagania te są określane słowem $\mathrm{m} \mathrm{in}^{14}$, które w swym pierwotnym rozumieniu oznaczało ,nauczanie”. W kontekście prawnym słowo to może być tłumaczone jako ,prawo”. Element społeczny przymierza synajskiego dotyczy więzi rodzinnej. Od chwili zawarcia tego traktatu, Izraelici są dziećmi Bożymi ${ }^{15}$. Odtąd każde wykroczenie w sferze kultowej i świeckiej jest wykroczeniem przeciwko Bogu. Dlatego też to przymierze ma charakter warunkowy, w przeciwieństwie do dwóch innych, ważnych przymierzy, jakie Bóg zawarł najpierw z Abrahamem ${ }^{16}$, a potem z Dawidem ${ }^{17}$. Chociaż posłuszeństwo wymogom przymierza synajskiego było niezbędne dla przetrwania Izraela we własnym kraju, to jednak nie określało ono w pełni relacji pomiędzy Bogiem a Izraelem, służyło tylko za dominujący obraz tej relacji. Rela-

8 B.W. Anderson, Przymierze, w: Stownik wiedzy biblijnej, red. B.M. Metzger. M.D. Coogan, Oficyna Wydawnicza Vocatio, Warszawa 1999, s. 666.

Wj 19,24.

10 Wj 19,4-6; 20,2.

11 Wj 20,3-23,33.

12 Zob. Przymierze, w: Stownik symboliki biblijnej, red. L. Ryken, J.C. Wilhoit, T. Longmann III, Oficyna Wydawnicza Vocatio, Warszawa 2003, s. 828.

13 Iz 31,1-3.

14 Pwt 31,25-26; Prz 3,1; 4,2; 7,2.

$15 \mathrm{Wj} 4,22$; Pwt 14,1.

16 Rdz 15.

$172 \mathrm{Sm} 7,14$. 
cja z Bogiem miała charakter trwały i dlatego złamanie przymierza, gdy do tego doszło, było tylko jego chwilowym zawieszeniem.

Nowe Przymierze zostaje zawarte nie według litery, lecz według Ducha ${ }^{18}$. Centrum tego przymierza jest misterium paschalne Chrystusa. Zasadniczym momentem zawarcia Nowego Przymierza przez Chrystusa jest Ostatnia Wieczerza, podczas której ustanawia On sakrament Eucharystii, zostawiając wierzącym w Niego swoje Ciało i Krew pod postaciami chleba i wina (por. Mt 26,28; Mk 14,24; Łk 22,20; 1 Kor 11,25) ${ }^{19}$. Przelewana Krew Chrystusa, oznaczająca Jego śmierć, spełnia zbawczą rolę ${ }^{20}$. Poprzez swoją śmierć Chrystus podejmuje ofiarę przebłagalną za grzechy ludzi. Dzięki tej ofierze urzeczywistnia się doskonałe zjednoczenie Boga $\mathrm{z}$ ludźmi na wieczność ${ }^{11}$. W ten sposób staje się również możliwe zjednoczenie pomiędzy samymi ludźmi. Tak więc Nowe Przymierze posiada charakter uniwersalny.

Do zgody, jako istotnego elementu umowy małżeńskiej, nadającej związkowi małżeńskiemu charakter przymierza, nawiązują w swoich wypowiedziach ojcowie Kościoła. Nauczają oni, że małżeństwo powstaje przez wzajemną zgodę ${ }^{22}$. Pogląd taki, jako wyraz nauczania Kościoła, nie był kwestionowany aż do czasów średniowiecza. Wówczas to zagadnienie zgody małżeńskiej stało się przedmiotem długotrwałej dyskusji, której kres położyło orzeczenie papieża Aleksandra III ${ }^{23}$. Wykładnia ta podtrzymywała wcześniejsze stanowisko Kościoła, że czynnikiem decydującym o zaistnieniu małżeństwa jest wzajemna zgoda mężczyzny i kobiety. Za takim stanowiskiem opowiedział się też Sobór Florencki, podkreślając, że przyczyną sprawczą małżeństwa jest w zwyczajnych warunkach wzajemna zgoda, wyrażona słowami w chwili jego zawierania ${ }^{24}$.Dokumentem kościelnym wskazującym na małżeństwo jako przymierze jest encyklika Piusa XI Casti connubii. Papież stwierdza w niej, że małżeństwo ustanowione jest przez Boga, jednak i ludzka wola bierze w nim udział. Małżeństwo powstaje na podstawie dobrowolnej zgody narzeczonego i narzeczonej. Ten dobrowolny akt woli, którym obydwie strony dają sobie nawzajem i przyjmują uprawnienia właściwe małżeństwu, jest do zawarcia prawdziwego małżeństwa tak konieczny, że nie może być zastąpiony żadnym innym czynnikiem. Wolność ta jednak dotyczy wyłącznie stwierdzenia,

182 Kor 3,6.

19 X. Leon-Dufour, Przymierze, w: Stownik teologii biblijnej, red. X. Leon-Dufour, Wyd. Pallottinum, Poznań 1990, s. 831.

20 E. Szymanek, Wykład Pisma Świętego Nowego Testamentu, Wyd. Pallottinum, Poznań 1990, s. 518 .

21 Hbr 10,11-22.

22 Posługują się oni terminami będącymi synonimami wyrażenia consensus (pacto coniugalis św. Ambroży: PLXVI,316; foedus - św. Jan Chryzostom: PGLVI, 802; pactum - św. Augustyn: PL XXXIV,1080).

23 M. Żurowski, dz. cyt., s. 76-77.

24 BF VII 593. 
czy kontrahenci rzeczywiście chcą zawrzeć małżeństwo i czy chcą je zawrzeć $\mathrm{z}$ daną osobą. Sama jednak natura małżeństwa jest całkowicie niezależna od wolnej woli człowieka do tego stopnia, że kto raz zawarł małżeństwo, ten już podlega jego Bożym prawom. Taka natura małżeństwa, wyjątkowa i jemu tylko właściwa, stawia je wyżej od kojarzeń się istot nierozumnych, dokonywanych jedynie pod wpływem ślepego instynktu natury ${ }^{25}$. Stąd też, chociaż encyklika Casti connubii podkreśla znaczenie i rolę miłości małżeńskiej, to jednak uwaga jest tu przesunięta na obowiązki i prawa, czyli płaszczyznę sprawiedliwości ${ }^{26}$. Zostaje w niej podkreślona rola umowy, którą obie strony zawierają ze sobą, dysponując w pełni wolnością. Umowa ta daje początek instytucji, którą jest małżeństwo.

Do małżeństwa jako przymierza nawiązał też Sobór Watykański II. Konstytucja duszpasterska o Kościele w świecie wspótczesnym , Gaudium et spes ” poucza, że „głęboka wspólnota życia i miłości małżeńskiej ustanowiona przez Stwórcę i unormowana Jego prawami, zawiązuje się poprzez przymierze małżeńskie, czyli przez nieodwołalną osobistą zgodę"27. Takie sformułowanie jest pogłębieniem trydenckiego sformułowania, że przyczyną sprawczą małżeństwa jest w zwyczajnych warunkach wzajemna zgoda wyrażona słowami w chwili jego zawierania ${ }^{28}$. Do urzeczywistnienia związku ustanowionego przez Boga potrzebna jest więc zgoda małżonków, która jest wzajemną aprobatą powstającego związku. Polega ona na wzajemnym i dobrowolnym udzieleniu i przyjęciu zobowiązań i praw. Ponadto narzeczeni wyrażają wzajemną i wiążącą zgodę na związek, który zawierają z własnej inicjatywy, ale go sami nie wymyślili. Co do swojej natury jest on określony przez prawo Boże naturalne i pozytywne, a przez Chrystusa uświęcony i podniesiony do godności sakramentalnej. Zgoda małżeńska zatem stanowi wzajemną, zobowiązującą decyzję na zawarcie związku o określonej i jedynej w swoim rodzaju wartości prawnej oraz teologicznej ${ }^{29}$. Stąd też podstawową rzeczą dla umowy małżeńskiej jest jej wzajemność. Sobór Watykański II wskazuje, że małżeństwo zawiązuje się poprzez przymierze, czyli przez wzajemną i nieodwołalną zgodę osobistą, wyrażoną słowami w chwili jego zawierania. Jest to odwołanie się do terminu mającego podstawowe znaczenie w ekonomii zbawienia. Tak więc, termin „przymierze” ma znaczenie ściśle religijne. W świetle tego stwierdzenia, małżeństwa, które nie pochodzi z ustanowienia ludzkiego lecz z ustanowienia Bożego nie można sprowadzać jedynie do związku czysto zewnętrznego, jedynie do płaszczyzny doczesnej, ale trzeba odkryć jego wewnętrzne bogactwo duchowe, czyli nadprzyrodzony wymiar.

$25 \mathrm{CCa} 609$.

26 Tamże, s. 6.

27 KDK 48.

28 BF VII 593.

29 M. Żurowski, dz. cyt., s. 78. 
Na małżeństwo jako przymierze wskazuje również w swoim nauczaniu Jan Paweł II. Przymierze to zawiązuje się wyłącznie przez świadomy i dobrowolny wybór, poprzez który mężczyzna i kobieta przyjmują wewnętrzną wspólnotę życia i miłości zamierzoną przez samego Boga. Jest to więc przymierze osób w miłości, co odpowiada społecznej naturze człowieka i sposobowi jego bytowania ${ }^{30}$. W rozumieniu Jana Pawła II punktem centralnym przymierza małżeńskiego i zarazem nadrzędnym motywem jego zawarcia jest miłość. Przymierze to nie jest wynikiem jakiejś niesłusznej ingerencji społeczeństwa czy państwa ${ }^{31}$.Do małżeństwa jako przymierza odwołuje się także ostatnia wersja Katechizmu Kościoła Katolickiego. W ujęciu tego dokumentu małżeństwo należy traktować jako przymierze ${ }^{32}$. U podstaw przymierza małżeńskiego stoi dobrowolnie zawarta przez mężczyznę i kobietę umowa $^{33}$. Wyraża się ona w wypowiedzianej wobec Kościoła zgodzie ${ }^{34}$. Jest to element nieodzowny. Bez niej małżeństwo nie istnieje $\mathrm{e}^{35}$.

Małżeństwo, będąc przymierzem, wiąże się z wzajemnymi zobowiązaniami ${ }^{36}$. Podstawowym zobowiązaniem wynikającym z przymierza małżeńskiego jest wierność ${ }^{37}$.Do nienaruszalnej wierności małżonków powinien też skłaniać fakt, że motywem zawarcia przymierza małżeńskiego jest miłość, domagająca się dochowania podjętych zobowiązań ${ }^{38}$. Ponieważ małżonkowie oddają się sobie wzajemnie w sposób ostateczny i całkowity, dlatego taka miłość domaga się wierności ${ }^{39}$. Na wierność, jako przedmiot tych zobowiązań, wskazuje też przysięga małżeńska ${ }^{40}$.

W świetle badań przeprowadzonych w latach 1997-2000 pod kierunkiem Janusza Mariańskiego wśród młodzieży szkół średnich z klas pierwszych i maturalnych z wybranych miast Polski, okazało się, że tylko 4,2 proc. (w poszczególnych przypadkach od 1,8 do 5,6 proc.) respondentów opowiedziało się za możliwością niewierności małżeńskiej, 11,6 proc. (szczegółowo od 8,4 do 13,6 proc.) warunkowało ją różnymi okolicznościami, a 76,2 proc. (od 73,2 do 81,2 proc.) opowiedziało się za dochowaniem wierności małżeńskiej ${ }^{41}$. Wyniki tych badań pokazały, że

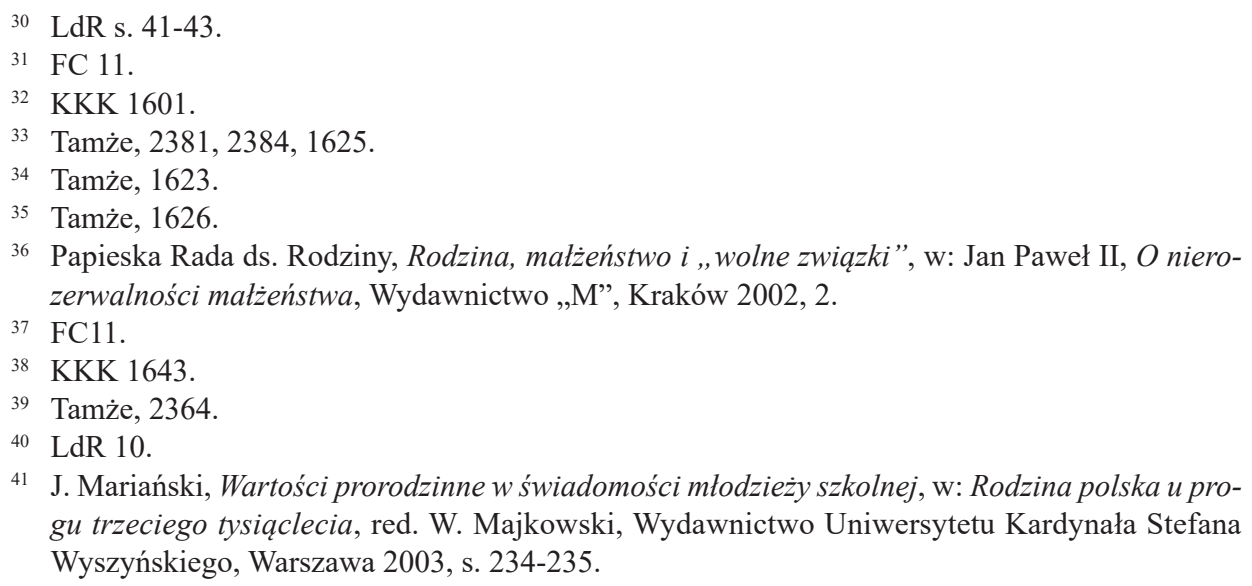

${ }^{41} \mathrm{~J}$. Mariański, Wartości prorodzinne w świadomości młodzieży szkolnej, w: Rodzina polska u progu trzeciego tysiaclecia, red. W. Majkowski, Wydawnictwo Uniwersytetu Kardynała Stefana Wyszyńskiego, Warszawa 2003, s. 234-235. 
zdrada małżeńska była dezaprobowana w wysokim stopniu przez środowisko młodzieży szkolnej, przy czym stopień ten był wyższy wśród kobiet niż wśród mężczyzn, co wskazało na wierność małżeńską, jako wartość szczególnie cenną dla małżeństwa.

Najniższe wskaźniki, jeśli chodzi o dochowanie wierności małżeńskiej, uzyskano w badaniach socjologicznych zrealizowanych w 1995 roku przez Edwarda Jarmocha w środowiskach wojskowych, wśród żołnierzy zasadniczej służby wojskowej. W świetle tych badań, tylko 58,2 proc. respondentów uznało, że zdrada małżeńska jest niedozwolona, 15,5 proc. uzależniało to od okoliczności, a 17,3 proc. ankietowanych aprobowało zdradę małżeńską. Wśród zawodowej kadry wojskowej wskaźniki były jeszcze gorsze, ponieważ tylko 41,7 proc. opowiedziało się za dochowaniem wierności małżeńskiej, 32,7 proc. uzależniało ocenę zdrady małżeńskiej od okoliczności, a 13,5 proc. aprobowało niewiernośćc ${ }^{42}$.

W świetle przeprowadzonych analiz można stwierdzić, że zobowiązanie do dochowania wzajemnej wierności przez małżonków, które wynika z faktu, że małżeństwo jest przymierzem, jest dalekie od ideału. Świadczy o tym sposób podejścia małżonków do zdrady małżeńskiej. Z omawianych badań wynika, że około 70 proc. ankietowanych opowiedziało się zdecydowanie za dochowaniem wierności małżeńskiej, czyli faktycznie uznało zdradę małżeńską za czyn zły, niezależnie od przyczyniających się do tego okoliczności. Należy podkreślić, że osoby religijne w większym stopniu, niż pozostałe, akceptowały wymóg wierności małżeńskiej. Badania pokazały, że najniższym stopniem akceptacji tej normy odznaczały się osoby rozwiedzione. W świetle badań okazało się także, że osoby dopuszczające niewierność małżeńską, niezależnie od okoliczności, znajdują się w zdecydowanej mniejszości. Około 30 proc. respondentów dopuszcza możliwość niewierności małżeńskiej, uzależniając to od okoliczności, lub nie ma własnego zdania na ten temat. Jest to wysoki wskaźnik w zestawieniu z faktem, że większość ankietowanych deklarowała potrzebę zawarcia ślubu kościelnego, który w świetle nauczania Kościoła, ściśle wiąże się z uroczystą przysięgą dochowania wierności małżeńskiej. Wynik ten nie może być uznany za zadowalający i dlatego staje się wyzwaniem do podjęcia adekwatnych działań pastoralnych.

W sytuacji znacznego zrelatywizowania wierności małżeńskiej w społeczeństwie polskim, duszpasterstwo rodzin powinno przypisywać priorytetową rolę inicjatywom pastoralnym podejmowanym na rzecz wzmocnienia wierności małżeńskiej. Działalność ta powinna być prowadzona z taktem, ponieważ dotyczy bardzo osobistej i intymnej sfery życia małżeńskiego. Niewierność dotyczy uczciwości małżeńskiej i płaszczyzny moralnej człowieka, wypacza wolę Bożą wobec przymierza małżeńskiego i uderza we wzajemne dążenie małżonków do świętości.

${ }^{42}$ E. Jarmoch, Religijność żotnierzy zasadniczej i zawodowej stużby wojskowej w warunkach przemian systemowych, Wydawnictwo Archidiecezji Warszawskiej, Warszawa 1998, s. 296. 
Konieczna staje się taka formacja sumienia ludzkiego, która pomogłaby w wyrabianiu cnoty czystości małżeńskiej. Cnota ta polega na posiadaniu przez człowieka uzdolnienia do postępowania zgodnego z wartością daru osoby współmałżonka. Wymaga to przestrzegania obiektywnych kryteriów strzegących wyłączności takiego pożycia i sensu wzajemnego oddawania się sobie ${ }^{43}$.

Duszpasterstwo rodzin, zmierzające do umocnienia małżonków w dochowywaniu wzajemnej wierności, powinno dowartościować pierwszeństwo środków nadprzyrodzonych ${ }^{44}$. Działalność pastoralna dokonuje się bowiem w ramach zbawczego posłannictwa Kościoła. To warunkuje użycie w nim środków właściwych temu posłannictwu, które określa się jako środki nadprzyrodzone ${ }^{45}$. Skutkiem uwzględnienia ich $\mathrm{w}$ duszpasterstwie rodzin jest nadprzyrodzone światło i łaska. Małżeństwo, będąc dziełem Bożym, potrzebuje Bożej łaski dla urzeczywistnienia siebie, co jest konieczne do przezwyciężenia negatywnych rezultatów grzechu pierworodnego. Wiele trudności w życiu małżeńskim jest ściśle związanych z osobistą wiarą i stopniem jej integracji z codziennym życiem. Pomocą w skutecznym rozwiązaniu tych trudności jest wzmocnienie wiary i przywrócenie zdolności do życia w łasce uświęcającej. Nie jest to jednak łatwe i dlatego zobowiązania małżeńskie powinny być osadzone w kontekście krzyża, czyli nosić znamiona ofiary, umartwienia i wyrzeczenia się siebie ${ }^{46}$. Powyższa postawa nie jest możliwa do osiągnięcia jedynie w oparciu o racje rozumowe. Jest ona integralnie wpisana w zbawcze misterium Jezusa Chrystusa. Kryzys współczesnych małżeństw wiąże się z kryzysem wiary i rozmijaniem się z Chrystusem. Jest to jeszcze jeden przykład na to, że w duszpasterstwie rodzin muszą mieć pierwszeństwo środki nadprzyrodzone.

Środkiem wspomagającym małżonków w dochowywaniu wierności małżeńskiej jest Słowo Boże. Duszpasterstwo rodzin, przepowiadaniu Słowa Bożego musi nadać znaczenie priorytetowe. Dlatego postuluje się, aby duszpasterze rodzin starali się naukę o małżeństwie i rodzinie przedstawiać wiernym w oparciu o pogłębione rozumienie biblijne i teologiczne. Należy stwarzać różne okazje ku takiemu głoszeniu, aby małżonkowie mogli usłyszeć i przyjąć Słowo Boże $e^{47}$, które przynosi nie tylko prawdę o małżeństwie, ale także udziela mocy do życia tą prawdą, w tym

43 Papieska Rada ds. Rodziny, Vademecum dla spowiedników o niektórych zagadnieniach moralnych dotyczacych życia matżeńskiego, w: Posoborowe dokumenty Kościoła katolickiego o matżeństwie i rodzinie, red. K. Lubowicki, Wydawnictwo „M”, Kraków 1999, t. 2, s. 493.

44 B. Mierzwiński, J. Wilk, R. Bieleń, Duszpasterstwo rodzin, w: Teologia pastoralna, red. R. Kamiński, Wydawnictwo Atla 2, Lublin 2002, t. 2, s. 416.

45 P. Poręba, Potrzeba naukowego duszpasterstwa rodzin, RTK 18 (1971) z. 3, s. 138-140.

46 J. Wilk, Duszpasterstwo rodzin: zasady praktycznego działania, RTK33 (1986) z. 6, s. 101.

47 Na potrzebę ewangelizacji małżeństwa i rodziny zwrócił mocną uwagę papież Paweł VI w swojej encyklice Evangelii nuntiandi wydanej w 1976 roku. Por. B. Mierzwiński, Elementy teologii praktycznej matzeństwa i rodziny, w: Teologia matżeństwa i rodziny, red. K. Majdański, Wydawnictwo Pallottinum, Poznań - Warszawa, 1980, s. 211-219. 
do realizowania powołania małżeńskiego i dochowania wierności małżeńskiej. W ten sposób duszpasterstwo rodzin przyczynia się do wzmacniania przymierza małżeńskiego.

W duszpasterstwie rodzin, zmierzającym do wspierania małżonków w dochowaniu wzajemnej wierności, należy brać pod uwagę fakt, że chociaż duszpasterstwo to $\mathrm{w}$ pewnym zakresie przynależy do zadań parafialnych poradni rodzinnych ${ }^{48}$, to z racji intymności tematyki, jaką jest wierność małżeńska, dobrym miejscem dla takiej posługi jest sprawowanie sakramentu pokuty i pojednania. Stwarza ono atmosferę zaufania i daje gwarancję dyskrecji, która jest konieczna w poruszaniu problemów związanych z niewiernością małżeńską. Przystępowanie przez penitenta do sakramentu pokuty i pojednania, świadczy, że posiada on świadomość własnej słabości i trudności w realizacji wierności małżeńskiej. Widząc, że dochowanie wierności małżeńskiej nie jest możliwe wyłącznie za pomocą ludzkich sił, liczy on na dobroć i miłosierdzie Boga. Dzięki temu penitent staje się zdolny do przyjęcia mocy Ducha Świętego, umożliwiającej urzeczywistnianie doskonałego daru z siebie samego w akcie małżeńskim, którego wyrazem jest dochowanie wierności małżeńskiej. Otrzymując w sakramencie pokuty i pojednania łaskę przebaczenia, człowiek zostaje wyzwolony z zatwardziałości serca, której wyrazem jest egoizm oraz szukanie korzyści, przyjemności, będących najczęściej przyczyną niewierności małżeńskiej. Może zaistnieć taka sytuacja, że penitent przystępuje do spowiedzi po długim okresie życia poza sakramentem pokuty i pojednania. Stwarza to wówczas szczególną okazję, aby problem niewierności małżeńskiej przedstawić w aspekcie wiary, jako odrzucenie zbawczych planów Boga względem małżeństwa i rodziny. Relatywizacja ocen moralnych w zachowaniu wiernych może przybierać charakter nieświadomości zła, jakie wynika z niewierności małżeńskiej. Wówczas spowiednik powinien uwrażliwić sumienie penitenta, wskazując na powołanie do świętości, jako najważniejszy cel wszystkich dążeń ludz$\mathrm{kich}^{49}$. Penitent musi jasno ujrzeć niebezpieczeństwa płynące z jego własnej słabości. Tej słabości, która jest ostatecznie złem i grzechem, nie może czynić kryterium swojego postępowania. W dalszej kolejności należy ukazać penitentowi inne jeszcze aspekty niewierności małżeńskiej: nieufność, wzajemną podejrzliwość małżonków, osłabienie więzi rodzinnej, obumieranie życia religijnego, życie w kłamstwie. To budzenie wrażliwości sumienia penitenta powinno się odbywać poprzez delikatne, konkretne i trafne pytania. Szczera odpowiedź na nie może

48 Konferencja Episkopatu Polski, Dyrektorium duszpasterstwa rodzin, Wyd. Fundacja Vita Familiae, Warszawa 2003, s. 33.

49 W. Gubała, Postuga spowiednika w świetle dokumentu Papieskiej Rady ds. Rodziny z 1997 r. Vademecum dla spowiedników. O niektórych zagadnieniach moralnych dotyczacych życia matżeńskiego, w: Spowiednik malżonków. Vademecum, red. C. Murawski, Wydawnictwo Diecezjalne, Sandomierz 2001, s. 53. 
prowadzić do zmiany dotychczasowego sposobu postępowania ${ }^{50}$.Stałe umacnianie w cnocie wierności małżeńskiej, jako wyraz permanentnej formacji sumienia, może się dokonywać poprzez codzienną praktykę sporządzania rachunku sumienia $^{51}$. Uzdolni to małżonków do konsekwentnego pokonywania swoich słabości na tej płaszczyźnie. Usprawni ich do przyjmowania nauczania Kościoła i pełniejszej akceptacji w swoim życiu Bożych planów ${ }^{52}$. Warto także zaproponować małżonkom stałe kierownictwo duchowe, jako szczególną pomoc w pogłębianiu życia duchowego, uzdalniającą do zachowania wierności małżeńskiej ${ }^{53}$.Stałe kierownictwo duchowe może stanowić skuteczną zaporę przeciwko intensywnej laicyzacji i relatywizacji wartości. Prowadzone w sposób pogłębiony, konsekwentnie i z duszpasterską troską, pomoże małżonkom w zachowaniu wierności małżeńskiej. Kierownictwo duchowe nie może wyręczać małżonków w podejmowaniu rozwiązań etycznych czy prawnych. Byłoby ono wówczas wypaczone. Ma ono tak kształtować sumienia małżonków, by byli zdolni oceniać własne czyny, jednoznacznie odróżniać dobro od zła, rozumieć, że grzech ma wymiar nie tylko indywidualny, ale i społeczny, zwłaszcza grzech niewierności małżeńskiej, który dotyka i niszczy całą rodzinę.

Małżeństwo jest związkiem posiadającym charakter przymierza. Oznacza to, że jest ono dobrowolną umową dwóch stron, a motywem jej zawarcia powinna być miłość, polegająca na całkowitym wzajemnym oddaniu. Z przymierza małżeńskiego wynikają przywileje i zobowiązania. Najważniejszym z tych zobowiązań jest dochowanie wierności małżeńskiej, dlatego cudzołóstwo jest zerwaniem przymierza małżeńskiego. Badania socjologiczne w zakresie postaw społeczeństwa polskiego wobec zdrady małżeńskiej pokazały, że następują zmiany nastawienia Polaków co do wymogu wierności małżeńskiej. Chociaż większość respondentów oceniło zdradę małżeńską jako czyn moralnie zły, zwłaszcza osoby deklarujące się jako głęboko wierzące, to jednak znaczna część badanych uzależniała dochowanie wierności małżeńskiej od zaistniałych okoliczności. Dlatego duszpasterstwo rodzin powinno wspierać małżonków w dochowywaniu wzajemnej wierności, wynikającej z istoty przymierza małżeńskiego i wyłączności daru miłości małżeńskiej. Działania pastoralne na tym polu wymagają szczególnie delikatnego podejścia i dużej dyskrecji, ponieważ dotykają najbardziej intymnych sfer życia czło-

50 P. Góralczyk, Wokót sakramentalnej postugi pojednania w życiu matżeńskim, w: Spowiednik matżonków, s. 66-69.

51 A. Bławat, Rachunek sumienia matżonków środkiem nawrócenia i wzajemnego doskonalenia, w: Postuga spowiedników w realizacji powołania matżeńskiego, Wyd. Fundacja Pomoc Rodzinie, Łomianki 1999, s. 92-99.

52 Papieska Rada ds. Rodziny, Vademecum dla spowiedników o niektórych zagadnieniach moralnych dotyczących życia matżeńskiego, w: Posoborowe dokumenty Kościoła katolickiego o matżeństwie i rodzinie, dz. cyt., t. II, 12.

53 W. Jankowski, Kierownictwo duchowe w duszpasterstwie rodzin, w: Postuga spowiedników w realizacji powotania matzeńskiego, Wyd. Fundacja Pomoc Rodzinie, Łomianki 1999, s. 111-119. 
wieka, Z racji istoty wierności małżeńskiej, działania te powinny koncentrować się na właściwej formacji sumienia ludzkiego, co pomoże w umacnianiu cnoty czystości. Szczególnie sprzyjającą do tego okolicznością jest spowiedź św. i kierownictwo duchowe.

\section{Bibliografia}

Anderson B.W., Przymierze, w: Stownik wiedzy biblijnej, red. B.M. Metzger, M.D. Coogan, Oficyna Wydawnicza Vocatio, Warszawa 1999.

Bławat A., Rachunek sumienia malżonków środkiem nawrócenia i wzajemnego doskonalenia, w: Postuga spowiedników w realizacji powołania matzeńskiego, Wyd. Fundacja Pomoc Rodzinie, Łomianki 1999.

Breviarium fidei. Wybór doktrynalnych wypowiedzi Kościoła, opr. S. Głowa, I. Bieda, Wyd. Księgarnia św. Wojciecha, Poznań 2001.

Góralczyk P., Wokót sakramentalnej posługi pojednania w życiu matżeńskim, w: Spowiednik malżonków. Vademecum, red. C. Murawski, Wydawnictwo Diecezjalne, Sandomierz 2001.

Góralski W., Kościelne prawo matżeńskie, Płockie Wydawnictwo Diecezjalne, Płock 1987.

Gubała W., Postuga spowiednika w świetle dokumentu Papieskiej Rady ds. Rodziny z 1997 r. „Vademecum dla spowiedników. O niektórych zagadnieniach moralnych dotyczących życia matżeńskiego", w: Spowiednik matżonków. Vademecum, red. C. Murawski, Wydawnictwo Diecezjalne, Sandomierz 2001, s. 53.

Jan Paweł II, List do rodzin, w: Posoborowe dokumenty Kościoła Katolickiego, red. K. Lubowicki, Wydawnictwo „M”, Kraków 1999, t. 2, s. 493.

Jan Paweł II, Adhortacja apostolska ,Familiaris consortio”, w: Posoborowe dokumenty Kościoła Katolickiego, red. K. Lubowicki, Wydawnictwo „M”, Kraków 1999, t. I, s. 428.

Jankowski W., Kierownictwo duchowe w duszpasterstwie rodzin, w: Posługa spowiedników w realizacji powołania matżeńskiego, Wyd. Fundacja Pomoc Rodzinie, Łomianki 1999.

Jarmoch E., Religijność żolnierzy zasadniczej i zawodowej stużby wojskowej w warunkach przemian systemowych, Wydawnictwo Archidiecezji Warszawskiej, Warszawa 1998.

Katechizm Kościoła Katolickiego, tekst polski, Wyd. Pallottinum, Poznań 1994.

Kodeks Prawa Kanonicznego, tekst łacińsko-polski, Wyd. Pallottinum, Poznań 1984.

Konferencja Episkopatu Polski, Dyrektorium duszpasterstwa rodzin, Wyd. Fundacja Vita Familiae, Warszawa 2003.

Obrzędy sakramentu matżeństwa dostosowane do zwyczajów diecezji polskich, Wyd. Księgarnia św. Jacka, Katowice 1996. 
Leon-Dufour X., Przymierze, w: Stownik teologii biblijnej, red. X. Leon-Dufour, Wyd. Pallottinum, Poznań 1990, s. 831.

Mariański J., Wartości prorodzinne w świadomości młodzieży szkolnej, w: Rodzina polska u progu trzeciego tysiaclecia, red. W. Majkowski, Wydawnictwo Uniwersytetu Kardynała Stefana Wyszyńskiego, Warszawa 2003, s. 234-235.

Mierzwiński B., Wilk J., Bieleń R., Duszpasterstwo rodzin, w: Teologia pastoralna, red. R. Kamiński, Wydawnictwo Atla 2, Lublin 2002, t. 2, s. 416.

Papieska Rada ds. Rodziny, Rodzina, malżeństwo $i$,wolne zwiąki”, w: Jan Paweł II, O nierozerwalności matżeństwa, Wydawnictwo „M”, Kraków 2002, s. 28.

Papieska Rada ds. Rodziny, Vademecum dla spowiedników o niektórych zagadnieniach moralnych dotyczacych życia matżenskiego, w: Posoborowe dokumenty Kościoła katolickiego o matżeństwie i rodzinie, K. Lubowicki, Wydawnictwo „M”, Kraków, 1999, t. 2, s. 493.

Pius XI, Encyklika , Casti connubii”, Wydawnictwo Księży Jezuitów, Kraków 1931.

Poręba P., Potrzeba naukowego duszpasterstwa rodzin, RTK 18 (1971) z. 3, s. $138-140$.

Stownik symboliki biblijnej, red. L. Ryken, J.C. Wilhoit, T. Longmann III, Oficyna Wydawnicza Vocatio, Warszawa 2003.

Sobór Watykański II, Konstytucje. Dekrety. Deklaracje, tekst łacińsko-polski, Wyd. Pallottinum, Poznań 1986.

Szymanek E., Wyktad Pisma Świętego Nowego Testamentu, Wyd. Pallottinum, Poznań 1990.

Wilk J., Duszpasterstwo rodzin: zasady praktycznego działania, RTK 33 (1986) z. 6, s. 101.

Żurowski M., Kanoniczne prawo matżeńskie Kościoła Katolickiego, Wyd. Księgarnia św. Jacka, Katowice 1987.

\section{Streszczenie}

Celem artykułu jest ukazanie nierozerwalności małżeństwa sakramentalnego, która wynika stąd, że przez ten sakrament nowożeńcy zostali włączeni w trwałą jedność, jaka istnieje między Chrystusem i Kościołem, będącym Jego Mistycznym Ciałem. Jak Chrystus-Głowa i Kościół tworzą jeden, nierozerwalny organizm, tak i małżonkowie, uświęceni przez łaskę Chrystusa, stanowią aż do śmierci jedno nierozerwalne ciało. Małżeństwo sakramentalne jest zatem czymś więcej niż czysto ludzką umową i przyrzeczeniem wzajemnej miłości, choć nawet ludzka tylko przysięga domaga się spełnienia tego, co się obiecało. Raz dane słowo zobowiązuje do wierności obietnicy. Sama natura miłości wymaga trwałości małżeń- 
stwa. Najważniejszym zobowiązaniem wynikającym z przymierza małżeńskiego jest dochowanie wzajemnej wierności.

Slowa kluczowe: matżeństwo, nierozerwalność, dochowanie wierności matżeńskiej, przymierze, Duszpasterstwo Rodzin

The Significance of the Marital Fidelity in the Contemporary Church Discourse

\begin{abstract}
Summary
This article discusses the sacramental marriage indissolubility which comes from the fact that the spouses are permanently incorporated into the unity that binds Jesus Christ and the Church, his Mystical Body. In the same way that Christ - the Head and his Church are a singular, united organism, also the spouses with the help of the Divine grace are one body till death sets them apart. The sacramental marriage is more than just a civil contract and a promise of love (even though the civil contract and the promise of love alone would bind the both parties to fulfil what was pledged). A solemn declaration once made compels us to be faithful to the word that was given. The very nature of love demands the marital indissolubility. The fundamental task undertaken at the celebration of marriage is being faithful to the other spouse.
\end{abstract}

Keywords: marriage, indissolubility, marital fidelity, union, the pastoral ministry of families 